\title{
Low-Dose Interleukin-2 as an Alternative Therapy for Refractory Lupus Nephritis
}

\author{
Xia Zhang (1) - Ruiling Feng $\cdot$ Miao Shao $\cdot$ Yifan Wang $\cdot$ \\ Xiaolin Sun · Jing He
}

Received: August 3, 2021 / Accepted: September 23, 2021 / Published online: October 7, 2021

(C) The Author(s) 2021

\begin{abstract}
Introduction: Low-dose interleukin-2 (IL-2) selectively restores disturbances of regulatory $\mathrm{T}$ cells (Treg) and conventional $\mathrm{T}$ cells, resulting in the induction of remission in patients with systemic lupus erythematosus. However, to date no research has been carried out on the efficacy of low-dose IL-2 in the treatment of refractory lupus nephritis (LN). The aim of the study reported here was to investigate the renal response to low-dose IL-2 in patients with refractory LN.

Methods: The study population comprised ten patients with refractory $\mathrm{LN}$ who failed to achieve complete response or who had relapsed while being treated with at least two conventional immunosuppressive agents. One treatment cycle consisted of IL-2 at a dose of 1 million IU administered subcutaneously every other day for 2 weeks followed by a 2 -week break. All patients received three cycles of IL-2 and were then followed up for another 12 weeks
\end{abstract}

Supplementary Information The online version contains supplementary material available at https:// doi.org/10.1007/s40744-021-00381-1.

X. Zhang · R. Feng - M. Shao - Y. Wang · X. Sun . J. He $(\square)$

Department of Rheumatology and Immunology, Peking University People's Hospital, 11 Xizhimen South street, Beijing 100044, China

e-mail: hejing1105@126.com without any increase in the dose of previous immunosuppressive agents and steroids.

Results: Of the ten patients enrolled in the study, seven (70\%) achieved $\geq 50 \%$ improvement in proteinuria at 12 weeks after initiating treatment with IL-2. Median proteinuria was significantly reduced by $50.3 \%$ at week 12 , from 1.83 (interquartile range [IQR] 1.23-3.21) g/ $24 \mathrm{~h}$ at baseline to 0.91 (IQR $0.52-1.60$ ) $\mathrm{g} / 24 \mathrm{~h}$ at 12 weeks $(P=0.005)$. This was accompanied by a $71 \%$ reduction in urine erythrocytes, from $64 / \mu \mathrm{l}$ (IQR $24-102 / \mu \mathrm{l}$ ) at baseline to $18 / \mu \mathrm{l}$ (IQR $2-20 / \mu \mathrm{l})$ at 12 weeks $(P=0.018)$. Anti-dsDNA was decreased from 27.9 (IQR 7.6-40.28) IU/ml at baseline to 14.1 (IQR 7.3-20.12) IU/ml $(P=0.021)$ at week 12 , while complements C3 and C4 were slightly increased $(P=0.445$, $P=0.241$, respectively). A significant expansion of Treg cells, from $9.3 \%$ at baseline to $16.6 \%$ at 12 weeks, was also found $(P<0.05)$. No serious adverse events occurred during the treatment period.

Conclusions: Low-dose IL-2 therapy may have a promising role in the treatment of refractory LN as an alternative and safe therapeutic approach. It may be used as multi-target combination therapy in clinical practice.

Keywords: Low-dose interleukin-2; Refractory lupus nephritis; Therapy 


\section{Key Summary Points}

Why carry out this study?

A deficiency of interleukin-2 (IL-2) and related disturbances in the homoeostasis of regulatory $\mathrm{T}$ cells (Treg) and conventional $\mathrm{T}$ cells (Tcon) play a crucial role in the pathogenesis of systemic lupus erythematosus, including renal involvement.

Low-dose IL-2 is known to promote expansion of Treg cells and might be potentially therapeutic for patients with refractory lupus nephritis (LN).

\section{What was learned from the study?}

Low-dose IL-2 therapy demonstrated a promising role in the treatment of refractory LN as an alternative and safe therapeutic approach.

It may be used as multi-target combination therapy in clinical practice.

\section{INTRODUCTION}

Lupus nephritis (LN) is the most common severe organ manifestation of systemic lupus erythematosus (SLE), with significant morbidity and mortality, characterized by a relapsing and remitting clinical course [1]. Despite best therapeutic efforts, there is a subset of patients who do not achieve complete renal response to conventional treatments; these patients are classified as having refractory LN. Treatments with immunosuppressants combined with targeted therapies, such as rituximab, have been efficacious and shown some promise, but there is still a need for randomized controlled trials investigating efficacy in LN specifically [2]. In addition, long-term use of these immunosuppressive agents is responsible for severe adverse events, such as infections and toxicity.
Therefore, effective and safe therapies are necessary in clinical practice.

There is a growing body of evidence which suggests that a deficiency of interleukin-2 (IL-2) and related disturbances in the homoeostasis of regulatory $\mathrm{T}$ cells (Treg) and conventional $\mathrm{T}$ cells (Tcon) play a crucial role in the pathogenesis of SLE, including renal involvement [3-6]. In one study, decreased serum IL-2 levels were associated with renal impairment [7]. In two other studies, Treg cells in the inflammatory infiltrate of kidney decreased with increasing pathogenic $\mathrm{CD}^{+} \mathrm{T}$ cells, in $\mathrm{LN}$ patients and lupus-prone mice, particularly during the most active phases of $\operatorname{LN}[8,9]$. In accordance with these findings, earlier studies indicated that low-dose IL-2 therapy selectively promoted Treg cells but inhibited T helper 17 (Th17) cells and follicular helper T cells (Tfh), which was accompanied by marked reductions of disease activity in patients with SLE [10-14]. Short-term IL-2 treatment of mice with active LN expanded the kidney-infiltrating Treg, inducing a clinical and histological amelioration of LN [15]. Hence, the association of homeostatic balance between Treg and Tcon with IL-2 deficiency and the reversibility of an imbalance by IL- 2 therapy suggest that low-dose IL-2 has therapeutic potential in LN. However, to date there has been no documentation of the clinical efficacy of low-dose IL-2 therapy for refractory LN.

The aim of this study was to analyze the efficacy and tolerability of low-dose IL-2 therapy in a series of patients with refractory LN.

\section{METHODS}

\section{Patients}

Ten patients with refractory LN were recruited from the Department of Rheumatology and Immunology in Peking University People's Hospital between February 2017 and December 2019. A diagnosis of refractory $L N$ was made if patients fulfilled the American College of Rheumatology renal criteria, failed to achieve complete response on at least two conventional immunosuppressive agents, including 
intravenous cyclophosphamide (CYC) and/or mycophenolate mofetil (MMF), or relapsed after achieving a complete response, thereby requiring enhanced treatment. In addition to receiving conventional therapy, patients were administered low-dose recombinant human IL2 (rhIL-2) (SL Pharma, Beijing, China) subcutaneously at a dose of 1 million IU every other day for 2 weeks, followed by a 2 -week break, for a total of three treatment cycles of IL-2 that were administered consecutively. Patients were then followed up for another 12 weeks. Concomitant steroids and immunosuppressive agents were tapered at the physician's discretion according to clinical response without increasing the dose.

Approval (reference number: 2016PHB19301) was obtained from the Peking University People's Hospital Ethics Committee prior to initiation of the study. Written informed consent (for participation and publication) was acquired from all patients involved. The study was performed in accordance with the Helsinki Declaration of 1975 and its later amendments.

\section{Clinical, Laboratory, and Immunological Assessments}

Renal response was defined as improvement in 24-h proteinuria. Other outcomes, including urinary red blood cells, serum creatinine and albumin, anti-double-stranded DNA (antidsDNA) antibodies, and complement levels, were assessed from baseline to week 12. Complete renal response was defined as proteinuria $<0.5 \mathrm{~g} /$ day with a normal or no worsening of glomerular filtration rate from baseline and no urinary sediments. Partial renal response was defined as $\geq 50 \%$ improvement in proteinuria with a normal or no deterioration in any other variable. Immunological analysis of peripheral blood mononuclear cells was performed at baseline and at week 12. Relative proportions of $\mathrm{CD}^{+} \mathrm{T}$ cells, including Treg, Th17 and Tfh subsets, were analyzed by flow cytometry using a FACSAria II flow cytometer (BD Biosciences, Franklin Lake, NJ, USA) and the FlowJo software package (Tree Star, BD Biosciences). Treg cells were defined as $\mathrm{CD}^{+} \mathrm{CD} 4^{+} \mathrm{CD} 25^{\text {high }} \mathrm{CD} 127^{\text {low }}$; Tfh cells were defined as
$\mathrm{CD}^{+} \mathrm{CD} 4^{+} \mathrm{CXCR}^{+} \mathrm{PD} 1{ }^{\text {high }} \mathrm{CCR} 7^{\text {low }}$; and Th 17 cells were defined as $\mathrm{CD}^{+} \mathrm{CD}^{+}{ }^{+} \mathrm{CXCR}^{-}$ $\mathrm{CCR}^{+}{ }^{\mathrm{CCR}} 7^{\text {low }}$.

\section{Statistical Analyses}

All statistical analyses were carried out using GraphPad Prism version 5.0 (GraphPad Software, San Diego, CA, USA) or the Statistical Package for the Social Sciences (SPSS) version 16.0 software (SPSS, IBM Corp., Armonk, NY, USA). Variables were presented as the median (interquartile range [IQR]). Differences in clinical characteristics, laboratory parameters, and immunological features between baseline and the indicated time points during IL-2 administration were evaluated with the Wilcoxon signed-rank test for continuous variables and the Chi-squared test for categorical variables. $P<0.05$ was considered to be significant.

\section{RESULTS}

\section{Patient Characteristics}

Ten patients with refractory LN (8 women, 2 men) were included in the study. Their baseline demographic and renal parameters are presented in Table 1. Median SLE disease duration was 93 months (IQR 34.5-138) and renal involvement duration was 33 months (IQR 16-96). Histological types of LN, based on the International Society of Nephrology/Renal Pathology Society 2003 classification, was class III in two cases, class IV in one case, class V in one case, and class IV and V in three cases each. Renal biopsy was not performed in three cases. Ten patients were on concomitant steroids (prednisone $5-22.5 \mathrm{mg} /$ day) and hydroxychloroquine (HCQ; $400 \mathrm{mg} /$ day) treatments. Regarding current immunosuppressive agents, six were on MMF (1000-2000 mg/day), three were on on CYC (400-600 mg every 2 weeks) and one was on azathioprine (AZA; $100 \mathrm{mg}$ /day). Five patients were prescribed angiotensin-converting enzyme inhibitors (ACEI), four patients angiotensin receptor 
Table 1 Baseline characteristics of patients with refractory lupus nephritis before the addition of low-dose interleukin-2

\begin{tabular}{|c|c|c|c|c|c|c|c|c|}
\hline Patients & $\begin{array}{l}\text { Age } \\
\text { (years) }\end{array}$ & Sex & $\begin{array}{l}\text { Duration of } \\
\text { SLE } \\
\text { diagnosis } \\
\text { (months) }\end{array}$ & $\begin{array}{l}\text { Renal } \\
\text { involvement } \\
\text { duration } \\
\text { (months) }\end{array}$ & $\begin{array}{l}\text { Renal } \\
\text { biopsy } \\
\text { classification }\end{array}$ & $\begin{array}{l}\text { Previous } \\
\text { treatments }\end{array}$ & $\begin{array}{l}\text { Concomitant } \\
\text { treatments }\end{array}$ & $\begin{array}{l}\text { Prednisone } \\
\text { dose } \\
\text { (mg/day) }\end{array}$ \\
\hline 1 & 32 & Male & 36 & 36 & $\begin{array}{l}\text { IV and V } \\
\text { class }\end{array}$ & $\begin{array}{c}\mathrm{HCQ}, \\
\text { CYC, } \\
\text { AZA }\end{array}$ & $\begin{array}{l}\text { HCQ } \\
0.4 \mathrm{~g} / \text { day } \\
\text { AZA } \\
100 \mathrm{mg} / \text { day } \\
\text { ARB }\end{array}$ & 5 \\
\hline 2 & 25 & Female & 132 & 132 & $\begin{array}{l}\mathrm{IV} \text { and } \mathrm{V} \\
\text { class }\end{array}$ & $\begin{array}{l}\text { HCQ, } \\
\text { CYC, } \\
\text { FK506, } \\
\text { rituximab }\end{array}$ & $\begin{array}{l}\text { HCQ } \\
0.4 \mathrm{~g} / \text { day } \\
\text { MMF } \\
1.5 \mathrm{~g} / \text { day } \\
\text { ACEI }\end{array}$ & 10 \\
\hline 3 & 34 & Female & 132 & 96 & IV class & $\begin{array}{l}\text { HCQ, } \\
\text { CYC, } \\
\text { AZA, } \\
\text { LEF, } \\
\text { rituximab }\end{array}$ & $\begin{array}{l}\mathrm{HCQ} \\
0.4 \mathrm{~g} / \text { day } \\
\mathrm{MMF} \\
1.0 \mathrm{~g} / \text { day } \\
\mathrm{ARB}\end{array}$ & 12.5 \\
\hline 4 & 36 & Male & 156 & 10 & $\mathrm{~V}$ class & $\begin{array}{l}\mathrm{HCQ}, \\
\mathrm{CYC}, \\
\mathrm{MMF}\end{array}$ & $\begin{array}{l}\text { HCQ } \\
0.4 \mathrm{~g} / \text { day } \\
\text { MMF } \\
2.0 \mathrm{~g} / \text { day } \\
\text { ACEI }\end{array}$ & 10 \\
\hline $5^{a}$ & 30 & Female & 30 & 24 & - & $\begin{array}{l}\text { HCQ, } \\
\text { CYC, } \\
\text { LEF }\end{array}$ & $\begin{array}{l}\text { HCQ } \\
0.4 \mathrm{~g} / \text { day } \\
\text { CYC } 0.6 \mathrm{~g} / 2 \mathrm{w} \\
\text { CCB }\end{array}$ & 22.5 \\
\hline 6 & 25 & Female & 84 & 84 & - & $\begin{array}{l}\mathrm{HCQ}, \\
\text { MMF }\end{array}$ & $\begin{array}{l}\text { HCQ } \\
0.4 \mathrm{~g} / \text { day } \\
\text { MMF } \\
1.5 \mathrm{~g} / \text { day } \\
\text { ACEI }\end{array}$ & 5 \\
\hline
\end{tabular}


Table 1 continued

\begin{tabular}{|c|c|c|c|c|c|c|c|c|}
\hline Patients & $\begin{array}{l}\text { Age } \\
\text { (years) }\end{array}$ & Sex & $\begin{array}{l}\text { Duration of } \\
\text { SLE } \\
\text { diagnosis } \\
\text { (months) }\end{array}$ & $\begin{array}{l}\text { Renal } \\
\text { involvement } \\
\text { duration } \\
\text { (months) }\end{array}$ & $\begin{array}{l}\text { Renal } \\
\text { biopsy } \\
\text { classification }\end{array}$ & $\begin{array}{l}\text { Previous } \\
\text { treatments }\end{array}$ & $\begin{array}{l}\text { Concomitant } \\
\text { treatments }\end{array}$ & $\begin{array}{l}\text { Prednisone } \\
\text { dose } \\
\text { (mg/day) }\end{array}$ \\
\hline 7 & 51 & Female & 240 & 96 & $\begin{array}{l}\text { IV and V } \\
\text { class }\end{array}$ & HCQ, CYC & $\begin{array}{l}\text { HCQ } \\
0.4 \mathrm{~g} / \text { day } \\
\text { MMF } \\
1.5 \mathrm{~g} / \text { day } \\
\text { ARB }\end{array}$ & 7.5 \\
\hline 8 & 41 & Female & 54 & 30 & III class & $\begin{array}{l}\mathrm{HCQ}, \\
\text { MMF }\end{array}$ & $\begin{array}{l}\text { HCQ } \\
0.4 \mathrm{~g} / \text { day } \\
\text { MMF } \\
1.5 \mathrm{~g} / \text { day } \\
\mathrm{ARB}\end{array}$ & 15 \\
\hline 9 & 26 & Female & 24 & 18 & - & HCQ, CYC & $\begin{array}{l}\mathrm{HCQ} \\
0.4 \mathrm{~g} / \text { day } \\
\text { CYC } 0.6 \mathrm{~g} / 2 \mathrm{w} \\
\text { ACEI }\end{array}$ & 12.5 \\
\hline 10 & 22 & Female & 102 & 10 & III class & HCQ, CYC & $\begin{array}{l}\text { HCQ } \\
\quad 0.4 \mathrm{~g} / \text { day } \\
\text { CYC } 0.4 \mathrm{~g} / 2 \mathrm{w} \\
\text { ACEI }\end{array}$ & 12.5 \\
\hline
\end{tabular}

$A C E I$ angiotensin-converting enzyme inhibitors, $A R B$ angiotensin receptor blockers, $A Z A$ Azathioprine, $C C B$ calcium channel blocker, $C Y C$ cyclophosphamide, $H C Q$ hydroxychloroquine, $L E F$ leflunomide, $M M F$ mycophenolate mofetil, $S L E$ systemic lupus erythematosus

a Patient 5 was treated with hemodialysis three times a week despite CYC and LEF therapy

blockers (ARB), and one patient calcium channel blocker (CCB).

\section{Efficacy}

Seven $(70 \%)$ of the ten patients achieved $\geq 50 \%$ improvement in proteinuria at 12 weeks after initiating IL-2 treatment. Median proteinuria was significantly reduced by $50.3 \%$ at week 12 , from 1.83 (IQR 1.23-3.21) $\mathrm{g} / 24 \mathrm{~h}$ at baseline to 0.91 (IQR 0.52-1.60) $\mathrm{g} / 24 \mathrm{~h}$ at 12 weeks $(P=0.005)$. This was accompanied by a $71 \%$ reduction in urine erythrocytes, from $64 / \mu \mathrm{l}$ (IQR
$24-102 / \mu \mathrm{l})$ at baseline to $18 / \mu \mathrm{l}(\mathrm{IQR} 2-20 / \mu \mathrm{l})$ at 12 weeks $(P=0.018)$ (Fig. 1a, b). Seven patients (70\%) achieved a full $(n=2 ; 20 \%)$ or partial $(n=5 ; 50 \%)$ renal response to low-dose IL-2 at 12 weeks. Compared to baseline, there was no significant change in serum albumin $(38.45$ [IQR 36.2-43.5] vs. 40 [IQR 37.1-42.4] g/l) and creatinine (78 [IQR 57.5-188.5] vs. 76 [IQR 63.5-127.5] $\mu \mathrm{mol} / \mathrm{l})$ at week $12(P=0.237, P=$ 0.5 , respectively). Anti-double-stranded DNA (anti-dsDNA) decreased from 27.9 (IQR 7.6-40.28) IU $/ \mathrm{ml}$ at baseline to 14.1 (IQR 7.3-20.12) $\mathrm{IU} / \mathrm{ml} \quad(P=0.021)$ at week 12 (Fig. 1C), while C3 and C4 slightly increased 

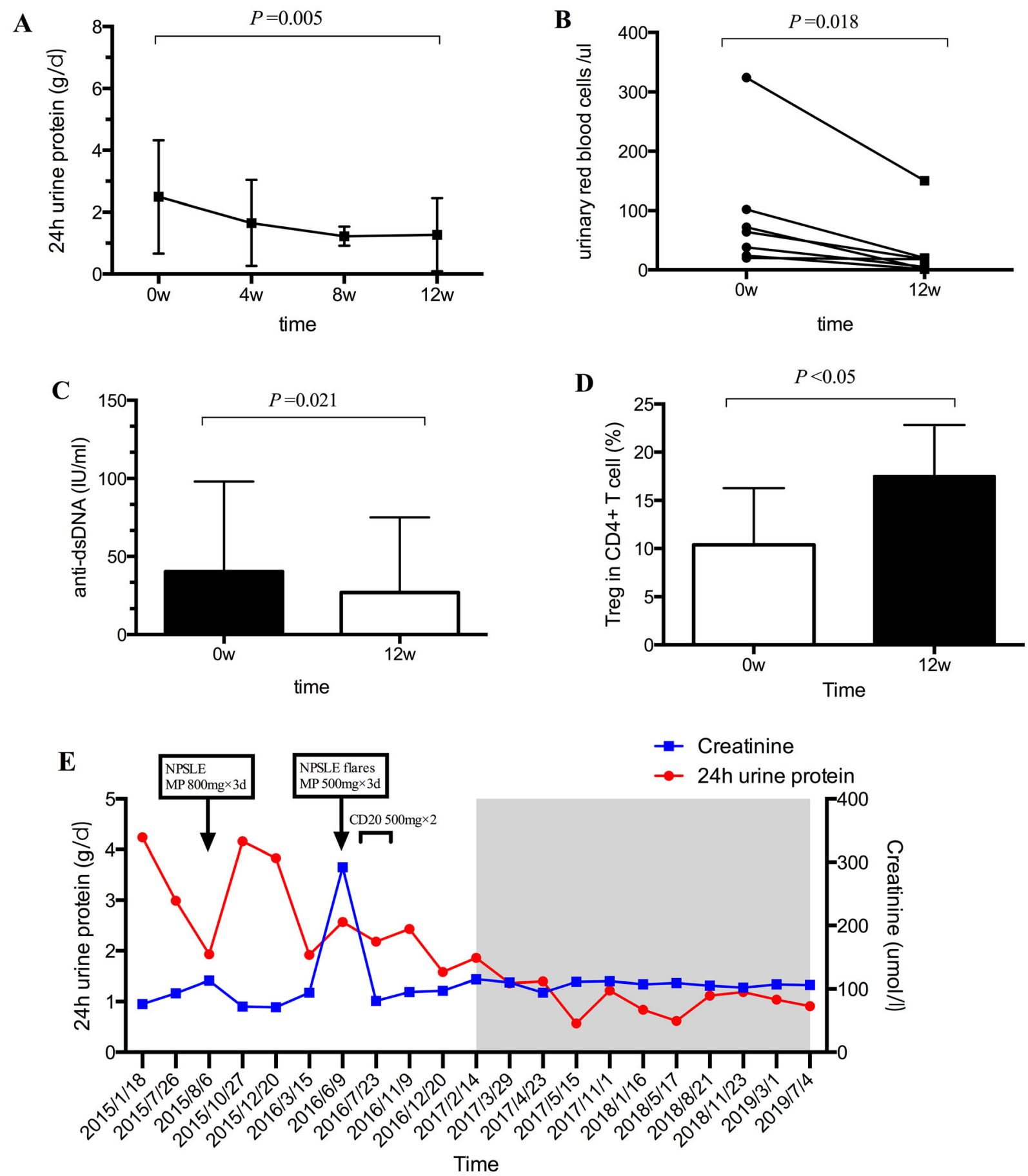
4Fig. 1 Renal, serological and immunological response to low-dose interleukin-2 (IL-2) therapy. a-d Changes in 24-h urine proteinuria (a) urinary blood cells (b) serum anti-dsDNA (c) and the proportion of Treg in $\mathrm{CD}^{+}{ }^{+}$cells (d) from baseline to 12 weeks after initiating IL-2 treatment. e One patient with multi-systemic involvement accompanied by NPSLE and lupus nephritis was resistant to conventional therapy and relapsed more than one time. When low-dose IL-2 was added to the therapeutic regemien in February 2017, the 24-h urine proteinuria decreased to the lowest level of $0.57 \mathrm{~g} /$ day throughout the course of systemic lupus erythematosus. Moreover, there were no flares during the maintenance therapy of IL-2 for a further 2 years. Gray areas indicate the periods on lowdose IL-2 therapy. Anti-dsDNA Anti-double-stranded DNA, MP Methylprednisolone, NPSLE neuropsychiatric systemic lupus erythematosus, Treg regulatory $\mathrm{T}$ cells

(0.964 [IQR 0.729-1.178] vs. 0.987 [IQR $0.611-1.245$ ] g/l and 0.178 [IQR 0.11-0.277] vs. 0.185 [IQR $0.127-0.324] \mathrm{g} / \mathrm{l}, \quad$ respectively) $(P=0.445, P=00.241$, respectively).

Patients were followed up for another 12 weeks after completion of the three cycles of IL-2 therapy. At follow-up week 24, median proteinuria ( $1 \mathrm{~g} / 24 \mathrm{~h}, \mathrm{IQR} 0.48-1.75)$ was still significantly reduced from the baseline level $(1.83 \mathrm{~g} / 24 \mathrm{~h}, \mathrm{IQR} 1.23-3.21) \quad(P=0.005)$, and urine erythrocyte count was also lower at this time point $(13 / \mu \mathrm{l}, \quad$ IQR $6-36)$ compared to baseline $(64 / \mu \mathrm{l}, \quad$ IQR $24-102) \quad(P=0.017)$ (Table 2). There was a trend that daily dose of prednisone decreased from 11.25 (IQR 6.88-13.13) $\mathrm{mg}$ at baseline to 10 (IQR 6.88-12.25) $\mathrm{mg}(P=0.066)$ at week 24 , although the difference was not statistically significant (Table 2).

In particular, patient no. 3 with multi-systemic involvement along with neuropsychiatric SLE and LN was resistant to conventional therapy and relapsed more than one time (Fig. 1E). The LN still failed to achieve complete response after rituximab therapy. When low-dose IL-2 was added to conventional therapy for 12 weeks, the $24 \mathrm{~h}$ proteinuria decreased from $1.86 \mathrm{~g} /$ day to the lowest level of $0.57 \mathrm{~g} /$ day throughout the course of SLE. To be mentioned, there were no flares during the maintenance therapy of IL-2 twice a week for further 2 years (Fig. 1E).

Flow cytometry analysis demonstrated lowdose IL-2 therapy induced a significant expansion of Treg cells from 9.3\% at baseline to $16.6 \%$

Table 2 Response of refractory LN patients during the course of low-dose IL-2 treatment and follow-up

\begin{tabular}{|c|c|c|c|c|c|}
\hline Characteristics & Baseline (week 0) & Week 12 & Week 24 & $\begin{array}{l}P \text { value (week } \\
12 \text { vs. } 0)\end{array}$ & $\begin{array}{l}P \text { value (week } \\
24 \text { vs. } 0 \text { ) }\end{array}$ \\
\hline Proteinuria, g/day & $1.83(1.23-3.21)$ & $0.91(0.52-1.60)$ & $1(0.48-1.75)$ & $0.005^{*}$ & $0.005^{*}$ \\
\hline $\begin{array}{l}\text { urinary blood cells, } \\
\qquad / \mu \mathrm{l}\end{array}$ & $64(24-102)$ & $18(2-20)$ & $13(6-36)$ & $0.018^{*}$ & $0.017^{*}$ \\
\hline $\begin{array}{l}\text { Serum CRE, } \\
\mu \mathrm{mol} / \mathrm{l}\end{array}$ & $78(57.5-188.5)$ & $76(63.5-127.5)$ & $75(56-126)$ & 0.5 & 0.225 \\
\hline C3, g/l & $0.964(0.729-1.178)$ & $0.987(0.611-1.245)$ & $1.029(0.731-1.38)$ & 0.445 & 0.753 \\
\hline C4, g/l & $0.178(0.11-0.277)$ & $0.185(0.127-0.324)$ & $0.253(0.136-0.35)$ & 0.241 & 0.753 \\
\hline $\begin{array}{l}\text { Anti-dsDNA, IU/ } \\
\mathrm{ml}\end{array}$ & $27.9(7.6-40.28)$ & $14.1(7.3-20.12)$ & $15.3(7-27.7)$ & $0.021^{*}$ & 0.172 \\
\hline $\begin{array}{c}\text { Prednisone, } \\
\text { mg/day }\end{array}$ & $11.25(6.88-13.13)$ & $11.25(6.88-12.5)$ & $10(6.88-12.5)$ & 0.102 & 0.066 \\
\hline
\end{tabular}

All values are presented as the median with the interquartile range (IQR) in parentheses

C3 Complement 3, C4 complement 4, CRE creatinine

* Significant difference at $P<0.05$ 
at week $12(P<0.05)$ (Fig. 1D), while Tfh and Th17 experienced no significant change $(P>0.05)$.

\section{Safety}

No serious adverse events during the IL-2 treatment period were observed. There were no severe nephrotoxic adverse effects. The most common adverse events were injection-site reactions, manifested as injection-site pain, redness, and swelling, which were observed in three of the ten $(33.3 \%)$ patients. These symptoms were resolved without intervention.

\section{DISCUSSION}

The present study demonstrated that low-dose IL-2 therapy promoted preferential expansion of Treg cells, thereby significantly reducing proteinuria by $50.3 \%$ in patients with refractory LN, with no serious adverse events. Low-dose IL2 therapy improved serum levels of anti-dsDNA antibodies and complements. Considering that our LN patients were resistant to previous therapies, it is encouraging to observe such renal responses. Therefore, IL-2-based immunotherapy for patients with refractory LN who fail to respond to standard therapies was identified to be effective and well tolerated as a reliable supplementary approach.

The concept of low-dose IL-2 therapy in autoimmunity and inflammation was inspired by the pivotal role of IL-2 in the development of Treg cells and the homeostatic balance between Treg and Tcon, in which Treg cells are essential in maintaining immune tolerance [3]. An earlier study showed a considerable decline of Treg in peripheral blood of SLE patients with nephritis compared to SLE patients without nephritis, suggesting that therapies targeting an expansion of Treg cells might have the potential to treat SLE, including renal involvement [6]. In addition, Antonella et al. demonstrated a decrease of FoxP3 ${ }^{+}$Treg cells in the inflammatory infiltrate of $\mathrm{LN}$, particularly during the most active phases of LN [8]. Low-dose IL-2 therapy has also been shown to restore CD25 expression in Treg and the homeostatic balance between Treg and Tcon and to be capable of reducing disease activity in lupus-prone mice and also in SLE patients with active disease [10-15]. However, none of the patients with refractory SLE in these studies had renal involvement. Our study showed that seven (70\%) of the ten patients with refractory LN achieved $\geq 50 \%$ improvement in proteinuria in response to low-dose IL-2 therapy by promoting preferential expansion of Treg cells. Low-dose IL-2 therapy also improved the serum levels of anti-dsDNA antibodies and complements. Our findings are broadly in line with those of previous studies of regulatory T-cells expanding responses to low-dose IL-2 therapy in vitro in patients with chronic kidney disease [16].

In LN, the Treg/Tcon proliferation ratio has been found to be substantially lower and to correlate with the SLE disease activity index, suggesting a potential role in the pathogenesis of renal damage in SLE [4-6]. Angelika et al. reported that long-term IL-2 treatment reduced the activity and proliferation of intrarenal Tcon, which was accompanied by a clinical and histological amelioration of LN in the (NZB $\times$ NZW) F1 mouse model [15]. In our study, there were no significant changes in Tfh and Th17 between baseline and treatment week 12 . One patient with multi-systemic involvement along with LN was resistant to conventional therapy and relapsed more than once. When low-dose IL-2 was added to the therapeutic regimen, the 24-h proteinuria decreased to the lowest level throughout the course of SLE. Moreover, there were no flares during the maintenance therapy of IL-2 for a further 2 years. This result implies that low-dose IL-2 therapy is a reasonable option in patients with refractory LN and might offer long-term preservation of renal function and prevention of renal flares. In our study, we did not monitor the related T-cell subsets for a long follow-up due to limited blood samples. Large-scale trials are therefore warranted.

The use of low-dose IL-2 therapy to restore Treg homeostasis is a unique therapeutic approach, as it differs from conventional treatment strategies that broadly and unselectively induce global immunosuppression. The benefit of low-dose IL-2 therapy may be in its use in multi-target combination therapy in clinical 
practice, with the aim to reduce the requirement for conventional immunosuppressants and alleviate the side effects of these treatments.

There are some limitations to our study. First, the small number of enrolled patients and the lack of a placebo group restrict the validity of our clinical findings. Although the clinical responses we report are encouraging in view of the refractory state of the treated population, these preliminary results need to be confirmed in large placebo-controlled trials. Secondly, the treatment time of IL-2 therapy was not long enough. There was only one patient who showed no flares when the low-dose IL-2 was added to the long-term maintenance therapy; this patient was resistant to conventional therapy and relapsed more than one time. Taking these limitations into account, we are unable to draw definite conclusions on the role of lowdose IL-2 in long-term preservation of renal function and prevention of renal flares.

\section{CONCLUSIONS}

In summary, our data provides preliminary evidence that low-dose IL-2 therapy is effective and safe and that it is a potential novel treatment for refractory LN, possibly in multi-target combination therapy in clinical practice. Larger, prospective, prolonged, randomized and controlled studies are urgently needed to validate our findings.

\section{ACKNOWLEDGEMENTS}

Funding. This work and the journal's Rapid Service Fee were supported by funds from Peking University People's Hospital Research and Development Funds (RS2020-01) and National Natural Science Foundation of China (NSFC) (81601417 and 32000639).

Authorship. All named authors meet the International Committee of Medical Journal Editors (ICMJE) criteria for authorship for this article, take responsibility for the integrity of the work as a whole, and have given their approval for this version to be published.

Authors' Contributions. Jing $\mathrm{He}$ and Xia Zhang contributed to the study design, data collection and analysis, outpatient follow-up, and manuscript writing. Ruiling Feng and Miao Shao participated in the study design and analyzed the immunological data. Yifan Wang and Xiaolin Sun were involved in data collection and interpretation. All authors participated in the drafting, critical revision, and approval of the final version of the manuscript.

Disclosures. Xia Xhang, Ruiling Feng, Miao Shao, Yifan Wang, Xiaolin Sun, and Jing He all have nothing to disclose.

Compliance with Ethics Guidelines. Approval (reference number: 2016PHB193-01) was obtained from the Peking University People's Hospital Ethics Committee prior to initiation of the study. Written informed consent (for participation and publication) was acquired from all patients involved. The study was performed in accordance with the Helsinki Declaration of 1975 and its later amendments.

Data Availability. The datasets generated during and/or analyzed during the current study are available from the corresponding author on reasonable request.

Open Access. This article is licensed under a Creative Commons Attribution-NonCommercial 4.0 International License, which permits any non-commercial use, sharing, adaptation, distribution and reproduction in any medium or format, as long as you give appropriate credit to the original author(s) and the source, provide a link to the Creative Commons licence, and indicate if changes were made. The images or other third party material in this article are included in the article's Creative Commons licence, unless indicated otherwise in a credit line to the material. If material is not included in the article's Creative Commons licence and your intended use is not permitted by statutory regulation or exceeds the permitted use, you will need to obtain permission directly from the 
copyright holder. To view a copy of this licence, visit http://creativecommons.org/licenses/bync/4.0/.

\section{REFERENCES}

1. Tsokos GC. Systemic lupus erythematosus. N Engl J Med. 2011;365:2110-21.

2. Cervera R, Mosca M, Ríos-Garcés R, et al. Treatment for refractory lupus nephritis: Rituximab vs triple target therapy. Autoimmun Rev. 2019;18(12): 102406.

3. Liao W, Lin JX, Leonard WJ. Interleukin-2 at the crossroads of effector responses, tolerance, and immunotherapy. Immunity. 2013;38:13-25.

4. Suárez-Fueyo A, Bradley SJ, Klatzmann D, Tsokos GC. T cells and autoimmune kidney disease. Nat Rev Nephrol. 2017;13:329-43.

5. Yap DY, Lai KN. Pathogenesis of renal disease in systemic lupus erythematosus - the role of autoantibodies and lymphocytes subset abnormalities. Int J Mol Sci. 2015;16:7917-31.

6. Xing Q, Wang B, Su H, Cui J, Li J. Elevated Th17 cells are accompanied by FoxP3+ Treg cells decrease in patients with lupus nephritis. Rheumatol Int. 2012;32:949-58.

7. Shao $\mathrm{M}, \mathrm{He} \mathrm{J}$, Zhang $\mathrm{R}$, et al. Interleukin-2 deficiency associated with renal impairment in systemic lupus erythematosus. J Interferon Cytokine Res. 2019;39:117-24.

8. Afeltra A, Gigante A, Margiotta DP, et al. The involvement of $\mathrm{T}$ regulatory lymphocytes in a cohort of lupus nephritis patients: a pilot study. Intern Emerg Med. 2015;10:677-83.

9. Humrich JY, Morbach H, Undeutsch R, et al. Homeostatic imbalance of regulatory and effector $\mathrm{T}$ cells due to IL-2 deprivation amplifies murine lupus. Proc Natl Acad Sci USA. 2010;107:204-9.

10. Humrich JY, von Spee-Mayer C, Siegert E, et al. Rapid induction of clinical remission by low-dose interleukin-2 in a patient with refractory SLE. Ann Rheum Dis. 2015;74:791-2.

11. He J, Zhang X, Wei Y, et al. Low-dose interleukin-2 treatment selectively modulates CD4(+) $\mathrm{T}$ cell subsets in patients with systemic lupus erythematosus. Nat Med. 2016;22:991-3.

12. von Spee-Mayer C, Siegert E, Abdirama D, et al. Low-dose interleukin-2 selectively corrects regulatory $\mathrm{T}$ cell defects in patients with systemic lupus erythematosus. Ann Rheum Dis. 2016;75:1407-15.

13. Jens YHCS, Elise $S$, et al. Low-dose interleukin-2 therapy in refractory systemic lupus erythematosus: an investigator-initiated, single-centre phase 1 and 2a clinical trial. Lancet Rheumatol. 2019;1:e44-54.

14. He J, Zhang R, Shao M, et al. Efficacy and safety of low-dose IL-2 in the treatment of systemic lupus erythematosus: a randomised, double-blind, placebo-controlled trial. Ann Rheum Dis. 2020;79: 141-9.

15. Rose A, von Spee-Mayer C, Kloke L, et al. IL-2 therapy diminishes renal inflammation and the activity of kidney-infiltrating $\mathrm{CD} 4^{+} \mathrm{T}$ cells in murine lupus nephritis. Cells. 2019;8:1234.

16. Li Y, Liu X, Wang W, et al. Low-dose IL-2 expands CD4(+) regulatory $\mathrm{T}$ cells with a suppressive function in vitro via the STAT5-dependent pathway in patients with chronic kidney diseases. Ren Fail. 2018;40:280-8. 